(2) Open Access Full Text Article

\title{
Anticancer activity of Nigella sativa (black seed) and its relationship with the thermal processing and quinone composition of the seed
}

This article was published in the following Dove Press journal:

Drug Design, Development and Therapy

18 June 2015

Number of times this article has been viewed

\section{Riad Agbaria \\ Adi Gabarin \\ Arik Dahan \\ Shimon Ben-Shabat}

Department of Clinical Pharmacology, School of Pharmacy, Faculty of Health

Sciences, Ben-Gurion University

of the Negev, Beer-Sheva, Israel
Correspondence: Shimon Ben-Shabat Department of Clinical Pharmacology, School of Pharmacy, Faculty of Health Sciences, Ben-Gurion University of the Negev, Beer-Sheva 84105, Israel

Tel +97286477363

Fax +972 86479303

Email sbs@bgu.ac.il
Abstract: The traditional preparation process of Nigella sativa (NS) oil starts with roasting of the seeds, an allegedly unnecessary step that was never skipped. The aims of this study were to investigate the role and boundaries of thermal processing of NS seeds in the preparation of therapeutic extracts and to elucidate the underlying mechanism. NS extracts obtained by various seed thermal processing methods were investigated in vitro for their antiproliferative activity in mouse colon carcinoma (MC38) cells and for their thymoquinone content. The effect of the different methods of thermal processing on the ability of the obtained NS oil to inhibit the nuclear factor kappa B (NF- $\mathrm{KB})$ pathway was then investigated in Hodgkin's lymphoma (L428) cells. The different thermal processing protocols yielded three distinct patterns: heating the NS seeds to $50^{\circ} \mathrm{C}, 100^{\circ} \mathrm{C}$, or $150^{\circ} \mathrm{C}$ produced oil with a strong ability to inhibit tumor cell growth; no heating or heating to $25^{\circ} \mathrm{C}$ had a mild antiproliferative effect; and heating to $200^{\circ} \mathrm{C}$ or $250^{\circ} \mathrm{C}$ had no effect. Similar patterns were obtained for the thymoquinone content of the corresponding oils, which showed an excellent correlation with the antiproliferative data. It is proposed that there is an oxidative transition mechanism between quinones after controlled thermal processing of the seeds. While NS oil from heated seeds delayed the expression of $\mathrm{NF}-\kappa \mathrm{B}$ transcription, non-heated seeds resulted in only $50 \%$ inhibition. The data indicate that controlled thermal processing of NS seeds (at $50^{\circ} \mathrm{C}-150^{\circ} \mathrm{C}$ ) produces significantly higher anticancer activity associated with a higher thymoquinone oil content, and inhibits the NF- $\mathrm{KB}$ signaling pathway.

Keywords: Nigella sativa, thermal processing, antiproliferative effect, thymoquinone, $\mathrm{NF}-\kappa \mathrm{B}$

\section{Introduction}

Nigella sativa (NS), or black seed, is an annual flowering plant of the Ranunculaceae family, which is native to the Mediterranean and the neighboring countries of Pakistan and India. Although the plant is not a significant component of the human diet, in the Middle East it is incorporated into the way of life and the daily $\operatorname{diet}^{1}$ as a spice and preservative. ${ }^{2}$ Black seed has been widely used for thousands of years to treat a variety of diseases and medical conditions, including asthma, high blood pressure, diabetes, inflammation, cough, headache, eczema, fever, dizziness, and influenza. ${ }^{2-4}$ Over the last five decades, numerous scientific studies have affirmed the pharmacological qualities of NS seeds, and demonstrated its anti-inflammatory, antibacterial, antihistamine, antidiabetic, anticancer, and antihypertensive activity. ${ }^{2}$

Extracts of NS contain volatile and non-volatile oils, amino acids, proteins, carbohydrates, alkaloids, nitrogen compounds, saponins, and minerals such 
as sodium, calcium, iron, and potassium; overall, more than 100 compounds have been isolated from black seed and their structure elucidated. ${ }^{1,2}$ Many studies have attributed the bulk of the pharmacological activity of NS to its quinone content, which includes thymoquinone (TQ) and its dimer dithymoquinone, thymohydroquinone (THQ), and thymol, which are known for their anticancer activity. The main phytochemical component of the volatile oil of NS is TQ, which accounts for $28 \%-45 \%$ of the oil. ${ }^{2,5,6}$ TQ has been thoroughly studied in vitro and in vivo, and shown to have a range of therapeutic properties, including analgesic, ${ }^{7}$ antihypertensive, lipid-lowering, ${ }^{7-9}$ anti-inflammatory, ${ }^{10}$ antibacterial, ${ }^{11}$ antifungal, ${ }^{12}$ antihistaminic,${ }^{13}$ antidiabetic, ${ }^{14,15}$ and anticancer activity. ${ }^{16-22}$ Inhibition of transcription of

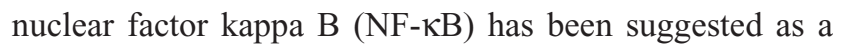
potential mechanism for the anticancer effects of TQ. ${ }^{6,23}$

Interviews with local traditional Bedouin herbal therapists reveal that the processing of NS seed to obtain a therapeutic oil follows a specific scheme that involves overnight soaking followed by drying, roasting for 5-6 minutes, milling, and filtration. In order to obtain only the oil from the seeds, the roasting step is not required, and the oil can be similarly obtained without this step; the fact that this allegedly unnecessary step has that has never been skipped, implies that this step may have a currently unknown role in the unique therapeutic qualities of NS oil.

The aims of this research were to investigate the role and boundaries of thermal processing of NS seed in preparation of therapeutic extracts, and to elucidate the mechanism behind the data obtained. The antiproliferative activity of NS extracts following various specifications of thermal processing of the seed were investigated in vitro in non-cancerous fibroblasts and in a mouse colon carcinoma (MC38) cell line. The effect of these thermal processing specifications on the TQ composition of the obtained NS oil was then studied and analyzed. Finally, the effect of thermal processing of the seed on the ability of the obtained NS oil to inhibit the NF- $\kappa$ B pathway was investigated in Hodgkin's lymphoma (L428) cells. Overall, this protocol allowed us to identify the relationship between seed processing, quinone content, and the anticancer activity of NS oil, which could aid in standardization of this important phytomedicinal plant.

\section{Materials and methods \\ Preparation of plant extract}

NS seeds were purchased from a local market, and stored as a voucher specimen. Water and methanol extracts of NS were prepared following exposure to different temperatures (by heating). After the different thermal processing, the seeds were washed, dried, and crushed manually to a powder with a mortar and pestle at room temperature in the absence of sunlight. Next, $15 \mathrm{~mL}$ of double-distilled water and $10 \mathrm{~mL}$ of hexane (95\%), dichloromethane (5\%) was added to $5 \mathrm{~g}$ of powder, with continuous vortexing until there was no further change in the color of the solution, which was then stored overnight at $4^{\circ} \mathrm{C}$ in sterile tubes covered by aluminum foil. The extract was centrifuged at $10,000 \times g$ for 30 minutes, and the upper oily and lower aqueous phases were separated and transferred to new tubes. The samples were later evaporated under reduced pressure using a rotary evaporator and then filtered through a Minisart filter and refrigerated until use. Precautions were taken to ensure the stability of the analysis samples, which are light-sensitive and heat-sensitive, since quinones of this type readily form radicals when exposed to light. Thus, immediately after preparation, vials containing the seed oil extract were covered by aluminum foil to them protect from light. Under these conditions, the extracts were stable for at least 2 months. ${ }^{12,24}$

\section{In vitro experiments}

\section{Cell culture}

The in vitro experiments utilized non-cancerous fibroblasts and two mouse tumor cell lines, ie, Hodgkin's lymphoma (L428) and colon carcinoma (MC38). The MC38 cells and non-cancerous fibroblasts were maintained in culture using high glucose Dulbecco's Modified Eagle's Medium, while the L428 cells were grown in Roswell Park Memorial Institute medium. All media were supplemented with 10\% fetal calf serum, $2 \mathrm{mM}$ L-glutamine, $100 \mathrm{U} / \mathrm{mL}$ penicillin, and $100 \mu \mathrm{g} / \mathrm{mL}$ streptomycin. The cells were in logarithmic growth at the time of use and were maintained at $37^{\circ} \mathrm{C}$ in a humidified atmosphere of $95 \%$ air and $5 \% \mathrm{CO}_{2}$. All drug powder were dissolved in double-distilled water to a concentration of $100 \mathrm{mM}$ or $10 \mathrm{mM}$ and stored at $-80^{\circ} \mathrm{C}$.

\section{Reverse-phase high-performance liquid chromatography}

Reverse-phase high-performance liquid chromatography was used to separate, identify, and quantify the pharmacologically active constituent, TQ, in NS seed extracts heated to different temperatures. Extraction of the constituent from the oil was carried out on a RP-C18 column, using an isocratic mobile phase of water:methanol:2-propanol (50:45:5\% v/v). Samples were filtered through a $0.45 \mu \mathrm{m}$ filter and deaerated before use. One-minute fractions were collected. Ultraviolet monitoring of the eluted solutes was carried out at $254 \mathrm{~nm}$ 
for TQ. Analyses were performed at ambient temperature at a flow rate of $2 \mathrm{~mL}$ per minute. ${ }^{5}$ Analytic departure time was determined by TQ 99\% standard, and the retention time of TQ was 16 minutes under these conditions. Electrospray ionization mass spectrometry of TQ in positive mode was found to be $165.12[\mathrm{M}+\mathrm{H}]^{+}$.

\section{$\mathrm{NF}-\kappa \mathrm{B}$ luciferase reporter gene assay}

The effects of NS extracts on NF- $\mathrm{KB}$ activity were determined using a NF- $\mathrm{KB}$ luciferase reporter gene assay. For initial selection of cells, we incubated L428 cells in Roswell Park Memorial Institute medium containing G418 $1 \mathrm{mg} / \mathrm{mL}$ for 2 weeks. L428 cells $\left(10^{6}\right.$ per well) expressing the NF- $\mathrm{KB}$ luciferase reporter gene were incubated in $1 \mathrm{~mL}$ of medium containing $10 \mu \mathrm{L}$ of methanolic extracts of NS seeds that were preheated to different temperatures for 2 hours. The cells were centrifuged at 2,000 rpm for 5 minutes, after which the supernatant was removed and the pellets were suspended in $70 \mu \mathrm{L}$ of lysate buffer. The lysates were incubated for 10 minutes at room temperature and centrifuged at $13,000 \mathrm{rpm}$ and $4^{\circ} \mathrm{C}$ for 1 minute. Next, $20 \mu \mathrm{L}$ samples from the lysates were mixed with $20 \mu \mathrm{L}$ of luciferase. The cells were then monitored by a luciferase reporter assay kit (Promega, Madison, WI, USA) according to the manufacturer's instructions. Measurements were carried out using a luminometer at $300 \mathrm{~nm}$. The data were normalized to the protein concentration in each lysate as measured by the Bradford method (Bio-Rad, Berkeley, CA, USA). ${ }^{25}$ Nuphar lutea, a water plant that has proven to be a successful inhibitor of NF- $\kappa \mathrm{B}$ transcription in cancer cells, was used as a positive control. ${ }^{25}$ Medium without treatment was used as the corresponding negative control.

\section{Results}

\section{In vitro evaluation and role of heating of NS oil on tumor cell proliferation}

In vitro experiments were carried out utilizing non-cancerous fibroblasts and a mouse colon carcinoma (MC38) cell line. Figure 1 shows that NS oil did not significantly change the rate of cell growth when compared with the control group, irrespective of thermal processing of the seeds. On the other hand, unheated NS oil decreased the growth rate of MC38 cancer cells by $40 \%$, and heating to $50^{\circ} \mathrm{C}$ for 10 minutes led to a $90 \%$ decrease in the cell growth rate (Figure 1). The $\mathrm{IC}_{50}$ for the unheated NS oil was found to be $1.4 \mu \mathrm{g} / \mathrm{mL}$, while the heating process yielded higher growth inhibition potency toward MC38 cells, with an $\mathrm{IC}_{50}$ of $0.6 \mu \mathrm{g} / \mathrm{mL}$.

In order to track the behavior of the oil after various thermal processing protocols, NS seeds were heated to

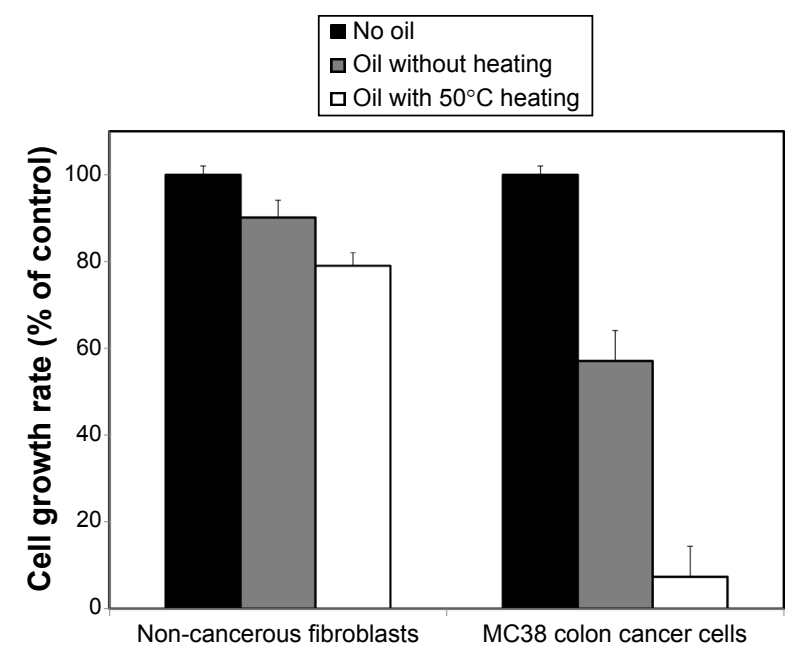

Figure I Effect of Nigella sativa oil extracted from non-heated seeds versus seeds heated to $50^{\circ} \mathrm{C}$ on growth rate of non-cancerous fibroblasts versus a mouse colon carcinoma (MC38) cell line. Data are presented as the mean \pm standard deviation $(n=4)$.

different temperatures (no heating, $25^{\circ} \mathrm{C}, 50^{\circ} \mathrm{C}, 100^{\circ} \mathrm{C}$, $150^{\circ} \mathrm{C}, 200^{\circ} \mathrm{C}$, and $250^{\circ} \mathrm{C}$ ) for 10 minutes, and the effect of the corresponding oil on proliferation of MC38 cancer cells was measured after 24, 48, and 72 hours of incubation (Figure 2). Three different patterns were observed in the different thermal processing protocol, ie, no effect, a mild effect, and a strong effect. Heating the NS seeds to temperatures of $50^{\circ} \mathrm{C}, 100^{\circ} \mathrm{C}$, or $150^{\circ} \mathrm{C}$ produced an oil with a strong ability to inhibit tumor cell growth, while NS oil from seeds without

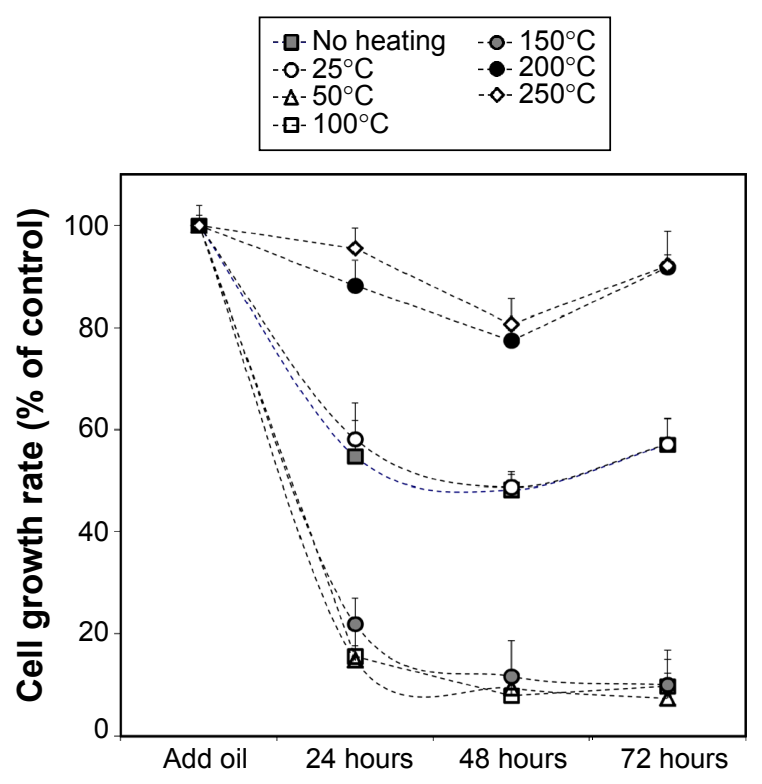

Figure 2 Effect of Nigella sativa oil extracted from seeds after different thermal processing protocols (no heating, $25^{\circ} \mathrm{C}, 50^{\circ} \mathrm{C}, 100^{\circ} \mathrm{C}, 150^{\circ} \mathrm{C}, 200^{\circ} \mathrm{C}$, and $250^{\circ} \mathrm{C}$ for 10 minutes) on growth rate of mouse colon carcinoma (MC38) cells following 24 , 48 , or 72 hours of incubation. Data are presented as the mean \pm standard deviation $(n=4)$. 
thermal processing (no heating or heating to $25^{\circ} \mathrm{C}$ ) had a mild antiproliferative effect on MC 38 cells. NS oil produced from seeds heated to temperatures of $200^{\circ} \mathrm{C}$ and $250^{\circ} \mathrm{C}$ did not show any significant effect on tumor cell proliferation. It should be noted that, in all cases, the effect of the different treatments on tumor cell proliferation was steady throughout the 72-hour study period (Figure 2).

\section{TQ content of NS oil following different thermal processing protocols}

Since the biological activity of NS oil is attributed mainly to TQ, we measured the effect of thermal processing of the NS seeds on the TQ content of the corresponding oil (Figure 3 ). NS seeds heated to $25^{\circ} \mathrm{C}$ had no effect on the relative amount of TQ when compared with the control group (no heating). The relative TQ content of the oil increased significantly when heated to $50^{\circ} \mathrm{C}, 100^{\circ} \mathrm{C}$, or $150^{\circ} \mathrm{C}$. In contrast, the extracts derived from seeds after heating to temperatures of $200^{\circ} \mathrm{C}$ or $250^{\circ} \mathrm{C}$ showed a significant reduction of TQ content.

These studies revealed an excellent correlation between the effect of NS oil on tumor cell growth rate and TQ content of the oil for the different thermal processing protocols (Figure 4). In both categories (effect on cell growth rate versus TQ content) a division into three groups was discovered, one with no effect $\left(200^{\circ} \mathrm{C}\right.$ and $\left.250^{\circ} \mathrm{C}\right)$, one with a mild effect (no heating and $25^{\circ} \mathrm{C}$ ), and one with a strong and significant effect $\left(50^{\circ} \mathrm{C}, 100^{\circ} \mathrm{C}\right.$, and $\left.150^{\circ} \mathrm{C}\right)$. The results show that controlled heating of NS seeds prior to the extraction process causes an increase in the relative TQ content, thereby increases the anticancer activity of the corresponding oil. Back calculation of the yield revealed that one gram of NS oil processed at $50^{\circ} \mathrm{C}$ yielded $8.3 \mathrm{mg}$ of TQ.

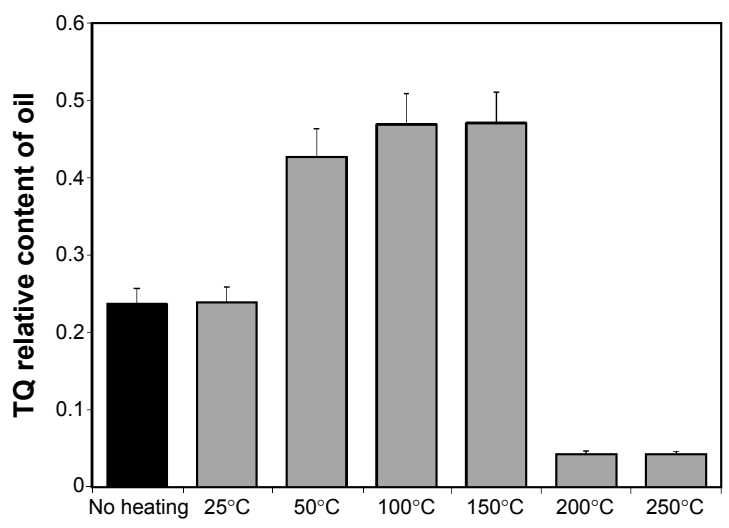

Figure 3 Effect of the different thermal processing protocols used for Nigella sativa seeds (no heating, $25^{\circ} \mathrm{C}, 50^{\circ} \mathrm{C}, 100^{\circ} \mathrm{C}, 150^{\circ} \mathrm{C}, 200^{\circ} \mathrm{C}$, and $250^{\circ} \mathrm{C}$ for 10 minutes) on the TQ content of the corresponding oil. Data are presented as the mean \pm standard deviation $(n=4)$.

Abbreviation: TQ, thymoquinone.

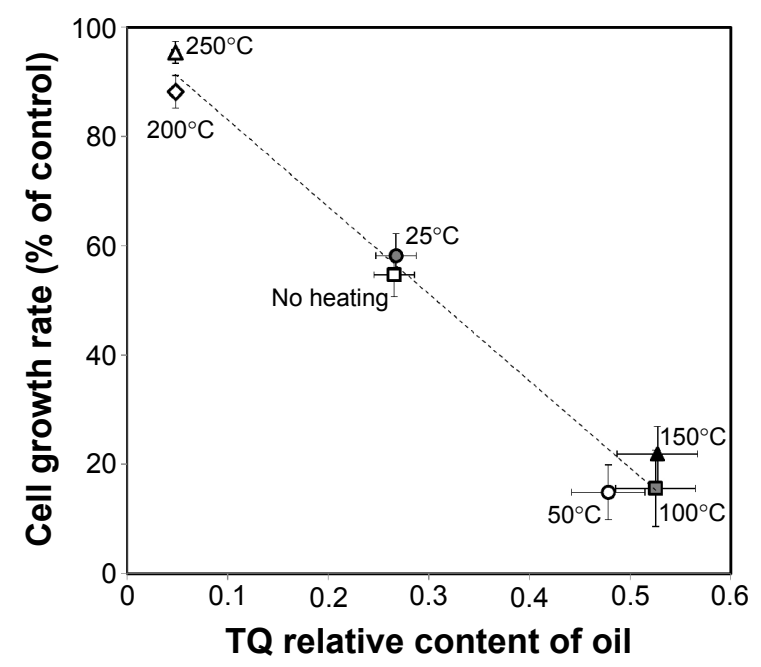

Figure 4 Correlation between effect of Nigella sativa oil on tumor cell growth rate and oil TQ content for the different thermal processing protocols used for the Nigella sativa seeds (no heating, $25^{\circ} \mathrm{C}, 50^{\circ} \mathrm{C}, 100^{\circ} \mathrm{C}, 150^{\circ} \mathrm{C}, 200^{\circ} \mathrm{C}$, and $250^{\circ} \mathrm{C}$ for 10 minutes). Data are presented as the mean \pm standard deviation $(n=4)$. Abbreviation: TQ, thymoquinone.

\section{Effect of heated NS seed oil on inhibition of the NF-KB pathway}

After determining the relationship between thermal processing of the NS seeds, the TQ content of the oil, and the antiproliferative effect on cancer cells, we investigated the effect of NS oil from heated versus non-heated seeds on the NF- $\kappa$ B signaling pathway (Figure 5). The results show that 2 hours of incubation with NS oil extracted from non-heated seeds resulted in $\sim 50 \%$ inhibition, while NS oil from heated seeds caused a complete inhibition in the expression of NF- $\kappa \mathrm{B}$ transcription, similar to the positive control (Figure 5).

\section{Discussion}

The main goal of this work was to study the effect of thermal processing of NS seeds on the activity and chemistry

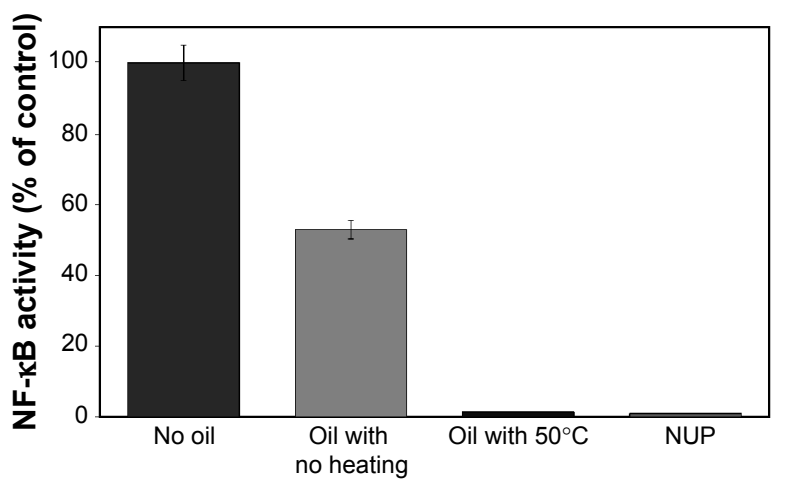

Figure 5 Effect of Nigella sativa oil from heated $\left(50^{\circ} \mathrm{C}\right)$ versus non-heated seeds on the NF-KB signaling pathway in Hodgkin's lymphoma (L428) cells expressing the NF-KB luciferase reporter gene. Extract of NUP was used as positive control, and medium without additives as negative control. Data are presented as the mean \pm standard deviation $(n=3)$.

Abbreviations: NUP, Nuphar Lutea plant; NF-кB, nuclear factor kappa B. 
profile of the corresponding oil. Previous studies reported that different storage, extraction, and isolation conditions may lead to a marked difference in the amounts of quinone constituents in the oil. ${ }^{5}$ Following analysis of the results presented here, we posit that controlled heating of the seeds during the preparation process leads to significant structural changes in the active ingredients of the oil, therefore increasing the antiproliferative activity against cancer cells. Most of the biological activity of NS is attributed to the quinone family, including dithymoquinone, THQ, and thymol, in addition to TQ, which are known for their specific anticancer effect in diverse human cancer cell lines. ${ }^{24}$ This specificity is because activation of NF- $\mathrm{KB}$ is significantly higher in cancerous cells than in normal cells, and since the mechanism of action of TQ involves NF- $\kappa B$ (Figure 5), the effect of TQ on cancer cells is much more profound than on normal cells. Studies comparing the anticancer activity and toxicity of various quinone compounds found differences in the degree of their effectiveness against various cancer cell lines. A previous study that examined and compared the anticancer activity of TQ and THQ found that although these compounds are both active in a dose-dependent manner, low doses of THQ were less effective than TQ against cancer cells. ${ }^{24}$ Following controlled thermal processing of the seeds, the level of TQ in the NS oil increased significantly (Figure 3), which can explain the higher activity of the oil from heated seeds when compared with oil from non-heated seeds.
Considering the chemical composition of the aforementioned quinone compounds, we hypothesize that thermal processing causes chemical changes such as oxidation, leading to modification and conversion between compounds, and accumulation of more potent compounds. We posit that controlled heating causes oxidation of thymol and converts it into THQ. The persistence of the heating process leads to an additional oxidative process that converts THQ into TQ, leading to accumulation of larger amounts of TQ (Figure 6). The photoisomerization of TQ, due to the presence of light, may lead to accumulation of its dimer, dithymoquinone (Figure 6).

We found that the chemical processes leading to accumulation of TQ occur at temperatures between $50^{\circ} \mathrm{C}$ and $150^{\circ} \mathrm{C}$. Heating the seeds to $200^{\circ} \mathrm{C}$ and above produces oil with no anticancer effect or ability to inhibit the NF- $\mathrm{\kappa B}$ activation pathway. Of note, the boiling point of TQ is $230^{\circ} \mathrm{C}-232^{\circ} \mathrm{C},{ }^{25}$ which explains the significant decrease in anticancer activity and in the relative amount of TQ after heating to high temperatures.

\section{Conclusion}

This study, like others in recent years, provides scientific support for the traditional use of NS oil. Our work showed that the cytotoxic activity of NS seed extracts involves dosedependent inhibition of cell growth and was more active in cancer cells than in non-cancerous cells. It was also found that heating of NS seeds before oil extraction produces oil
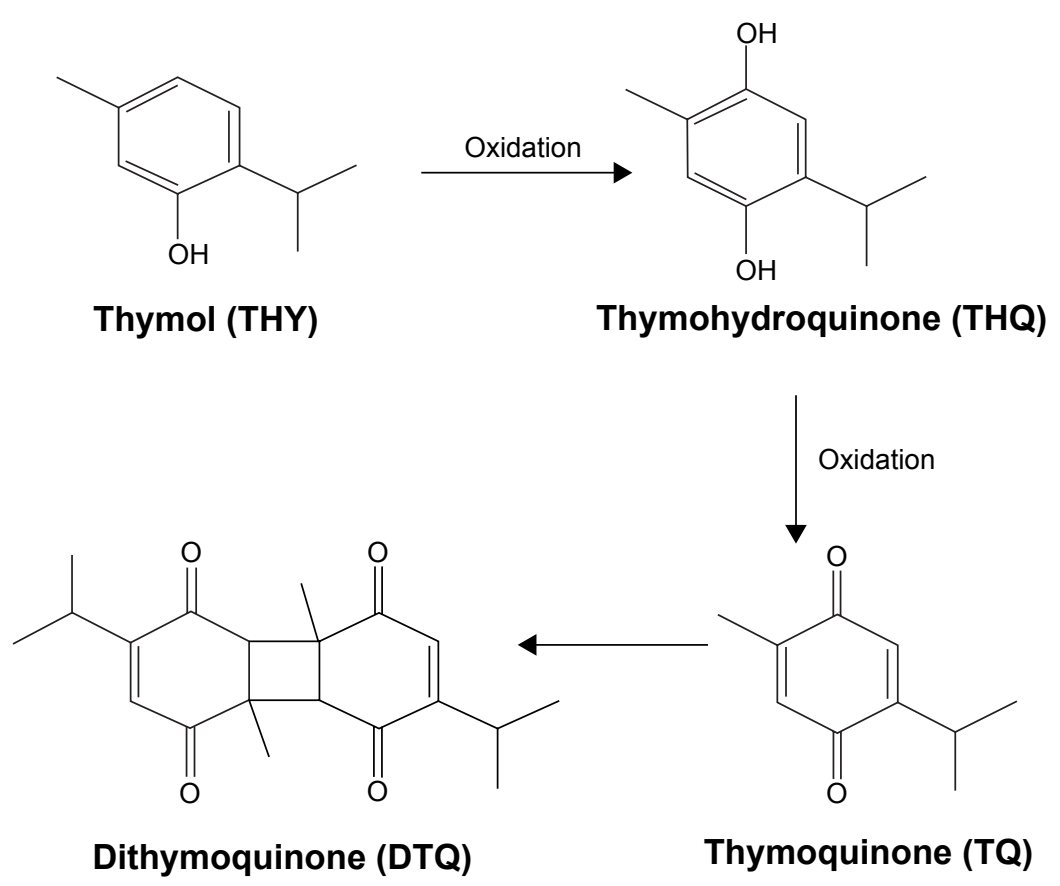

Figure 6 Hypothesized mechanism of transition between quinones by an oxidation process after controlled heating of Nigella sativa seeds. 
that is more effective against cancer cells. In addition, our results suggest that heating the seeds before preparation of the extract causes a change in the relative amount of TQ, which explains the differences in their anticancer activity. In conclusion, there is room for further scientific research on NS oil and seeds, including in in vivo models and further clinical trials.

\section{Disclosure}

The authors report no conflicts of interest in this work.

\section{References}

1. Gali-Muhtasib H, Roessner A, Schneider-StockR. Thymoquinone: a promising anti-cancer drug from natural sources. Int JBiochem Cell Biol.2006;38: 1249-1253.

2. Ali BH, Blunden G. Pharmacological and toxicological properties of Nigella sativa. Phytother Res. 2003;17:299-305.

3. Ait Mbarek L, Ait Mouse H, Elabbadi N, et al. Anti-tumor properties of blackseed (Nigella sativa L.) extracts. Braz J Med Biol Res. 2007;40: 839-847.

4. Baharetha HM, Nassar ZD, Aisha AF, et al. Proapoptotic and antimetastatic properties of supercritical $\mathrm{CO}_{2}$ extract of Nigella sativa Linn. against breast cancer cells. J Med Food. 2013;16:1121-1130.

5. Ghosheh OA, Houdi AA, Crooks PA. High performance liquid chromatographic analysis of the pharmacologically active quinines and related compounds in the oil of the black seed (Nigella sativa L). J Pharm Biomed Anal. 1999;19:757-762.

6. Abukhader MM. Thymoquinone in the clinical treatment of cancer: Fact or fiction? Pharmacogn Rev. 2013;7:117-120.

7. Abdel-Fattah AM, Matsumoto K, Watanabe H. Antinociceptive effects of Nigella sativa oil and its major component, thymoquinone, in mice. Eur J Pharmacol. 2000;400:89-97.

8. Bashandy SA. Effects of Nigella sativa oil on liver and kidney functions of adult and senile rats. Egypt J Pharm Sci. 1996;37:313-327.

9. Zaoui A, Cherrah Y, Lacaille-Dubois MA, Settaf A, Amarouch H, Hassar M. [Diuretic and hypotensive effects of Nigella sativa in the spontaneously hypertensive rat]. Therapie. 2000;55:379-382. French.

10. Mutabagani A, El-Mahdy, Samiha H. Study of anti-inflammatory activity of Nigella sativa L. and thymoquinone in rats. Saudi Pharm J. 1997;5: $110-113$.
11. Sokmen A, Jones BM, Erturk M. The in vitro antibacterial activity of Turkish medicinal plants. J Ethnopharmacol. 1999;67:79-86.

12. Khan MA, Ashfaq MK, Zuberi HS, Mahmood MS, Gilani AH. The in vivo antifungal activity of the aqueous extract from Nigella sativa seeds. Phytother Res. 2003;17:183-186.

13. Chakravarty N. Inhibition of histamine release from mast cells by nigellone. Ann Allergy. 1993;70:237-242.

14. Salem ML. Immunomodulatory and therapeutic properties of the Nigella sativa L. seed. Int Immunopharmacol. 2005;5:1749-1770.

15. Hassanim NI, Hassan FM. A preliminary study on the effect of Nigella sativa seeds on hypoglycemia. Vet Med J Giza. 1996;44:699-708.

16. Tariq M. Nigella sativa seeds: folklore treatment in modern day medicine. Saudi J Gastroenterol. 2008;14:105-106.

17. Worthen DR, Ghosheh OA, Crooks PA. The in vitro anti-tumour activity of some crude and purified components of black seeds, Nigella sativa L. Anticancer Res. 1998;18:1527-1532.

18. Jafri SH, Glass J, Shi R, Zhang S, Prince M, Kleiner-Hancock H. Thymoquinone and cisplatin as a therapeutic combination in lung cancer: in vitro and in vivo. J Exp Clin Cancer Res. 2010;29:29-87.

19. Roepke M, Diestel A, Bajbouj K, et al. Lack of p53 augments thymoquinone-induced apoptosis and caspase activation in human osteosarcoma cells. Cancer Biol Ther. 2007;6:160-169.

20. Shoieb AM, Elgayyar M, Dudrick PS, Bell JL, Tithof PK. In vitro inhibition of growth and induction of apoptosis in cancer cell lines by thymoquinone. Int J Oncol. 2003;22:107-113.

21. El-Mahdy MA, Zhu Q, Wang QE, Wani G, Wani AA. Thymoquinone induces apoptosis through activation of caspase- 8 and mitochondrial events in p53-null myeloblastic leukemia HL-60 cells. Int J Cancer. 2005; 117:409-417.

22. Tan M, Norwood A, May M, Tucci M, Benghuzzi H. Effects of (-)epigallocatechin gallate and thymoquinone on proliferation of a PANC-1 cell line in culture. Biomed Sci Instrum. 2006;42:363-371.

23. Sethi G, Ahn KS, Aggarwal BB. Targeting nuclear factor- $\kappa B$ activation pathway by thymoquinone: role in suppression of antiapoptotic gene products and enhancement of apoptosis. Mol Cancer Res. 2008;6: 1059-1070.

24. Penecilla GL, Magno CP. Antibacterial activity of extracts of twelve common medicinal plants from the Philippines. J Med Plants Res. 2011; 5:3975-3981.

25. Ozer J, Eisner N, Ostrozhenkova E, et al. Nuphar lutea thioalkaloids inhibit the nuclear factor $\mathrm{kB}$ pathway, potentiate apoptosis and are synergistic with cisplatin and etoposide. Cancer Biol Ther. 2009;8: 1860-1868.
Drug Design, Development and Therapy

\section{Publish your work in this journal}

Drug Design, Development and Therapy is an international, peerreviewed open-access journal that spans the spectrum of drug design and development through to clinical applications. Clinical outcomes, patient safety, and programs for the development and effective, safe, and sustained use of medicines are a feature of the journal, which

\section{Dovepress}

has also been accepted for indexing on PubMed Central. The manuscript management system is completely online and includes a very quick and fair peer-review system, which is all easy to use. Visit http://www.dovepress.com/testimonials.php to read real quotes from published authors. 